\title{
Effect of some newer insecticides against okra aphids, Aphis gossypii
}

\author{
S.M. GAIKWAD*1, P.N. MAGAR ${ }^{2}$ AND A.S. DAMRE ${ }^{1}$
}

${ }^{1}$ Mahatma Phule Krishi Vidyapeeth, Rahuri, AHMEDNAGAR (M.S.) INDIA

${ }^{2}$ Entomology section, College of Agriculture, PUNE (M.S.) INDIA

\section{ARITCLE INFO}

$\begin{array}{ll}\text { Received } & \text { : } 29.03 .2014 \\ \text { Revised } & : 06.09 .2014 \\ \text { Accepted } & \text { : } 17.09 .2014\end{array}$

\section{KEY WORDS :}

Okra, Aphids, Aphis gossypii, Insecticides

*Corresponding author: Email: shardgiakwad@gmail.com

\begin{abstract}
The field experiment was carried out to evaluate the effect of newer insecticide molecules against sucking pest complex of okra. Thiamethoxam @ $25 \mathrm{~g}$ a.i./ha recorded 1.38 overall average survival of aphid population on plant and was significantly superior over all other treatments. Fipronil @ $50 \mathrm{~g}$ a.i./ha was found to be at par with thiamethoxam @ $25 \mathrm{~g}$ a.i./ha and recorded 1.68 overall average survival aphids/3leaves/plant. The next best treatment, buprofezin@156 g a.i./ha, recorded 2.44 overall average survival aphids/ 3leaves /plant. Spinosad@50 g a.i./ha and imidacloprid @ $25 \mathrm{~g}$ a.i./ha were at par with buprofezin @ 156 $\mathrm{g}$ a.i./ha and recoded 2.74 and 2.81 overall average survival aphids/ 3leaves /plant, respectively. Abamectin@100 g a.i./ha was found to be less effective recording 4.10 average survival aphids/ 3leaves /plant.
\end{abstract}

How to view point the article : Gaikwad, S.M., Magar, P.N. and Damre, A.S. (2014). Effect of some newer insecticides against okra aphids, Aphis gossypii. Internat. J. Plant Protec., 7(2) : 462-464. 